\title{
Preschool Teachers' Views on World Citizenship Education
}

\author{
Şehnaz CEYLAN*
}

Received: 19 February 2013

Accepted: 23 September 2013

\begin{abstract}
The current study aimed at investigating views of preschool teachers on the concept of world citizenship education and teaching world citizenship in the preschool years. The Teaching World Citizenship in the Twenty-First Century Survey developed by Gallayan (2008) was used in this research. The sample consisted of 345 preschool teachers involving in in-service training programs and seminars held by the Ministry of National Education in the following cities of Turkey: Yalova, Afyonkarahisar, Eskişehir, Aksaray and Rize. It was found out that majority of the teachers believed that preschool teaching programs should consider world citizenship and wanted to teach it to children. However, teacher education received and teaching experiences gained did not enable them to teach world citizenship to children.
\end{abstract}

Key words: Teaching world citizenship, preschool teaching, preschool teachers

\section{Extended Abstract}

Purpose and Significance: Training children, in the early childhood years considered as critical time for individuals, to improve their knowledge, skills and attitudes required for world citizenship is of great importance. Many researchers have pointed out that world citizenship education should be given since the preschool years. On the other hand, studies on world citizenship education have mostly focused on training of pre-service teachers and upper levels of education. Also, in Turkey, the concept of world citizenship has recently been taken into consideration and there has been a very limited number of studies in this field. In this sense, the current study aimed at investigating views of preschool teachers on world citizenship education.

Methods: The sample consisted of 345 preschool teachers involving in in-service training programs and seminars held by the Ministry of National Education (MoNE) in the following cities of Turkey: Yalova, Afyonkarahisar, Eskişehir, Aksaray and Rize. Of the sample, $60.9 \%$ expressed that they worked in kindergartens under the roof of primary schools of the MoNE and 30.1\% worked in independent kindergartens of the MoNE. In order to gather data, "General Information Form” was used to determine demographic characteristics such as gender, age, the place they lived in with their families, and the original form of Teaching World Citizenship in the Twenty-First Century Survey to explore views of pre-service preschool teachers on teaching children how to be a "world citizen". The survey was developed by Gallavan (2008) and administered to pre-service K-12 teachers. The survey is comprised of 11 questions in total, five open-ended and six yes-no questions. The data were first statistically analyzed 
through the SPSS 15.0 for Windows and views of teachers on world citizenship were analyzed through calculating descriptive statictics (e.g. frequencies, percentages) and content analysis was also conducted.

Discussion and Conclusions: Increasing the number of people who are aware of being a world citizen is one of the factors behind individual, institutional and international success. The concept of world citizenship enables children to develop sensitivity. In particular, it is necessary to teach them the rights and responsibilities of being a human, being a world citizen since the early years. Preschool education gives children an opportunity to interact with others and develop their perspectives on the world. Therefore, preschool teachers have a great responsibility to make children learn the concept of world citizenship. Depending on the results of this research, it was concluded preschool teaching programs should consider world citizenship and wanted to teach it to children. However, teacher education received and teaching experiences gained did not enable them to teach world citizenship to children. In addition, the majority of the teachers equated being a world citizen with equal rights, freedom and democracy. Most of the teachers pointed out that the program content should offer different cultural activities in order to prepare preschool children for world citizenship. Most of the teachers expressed that preschool children should be given learning opportunities to learn by doing and experiencing in order to prepare them for world citizenship and courses, seminars, meetings, conferences and workshops should be organized for their development. Among all concerns of the teachers in teaching preschool children how to become a world citizen, impossibility of teaching children to be a world citizen due to lack of knowledge came the first. 


\title{
Okul Öncesi Öğretmenlerinin Dünya Vatandaşlığı Eğitimi İle İlgili Görüşleri
}

\author{
Şehnaz CEYLAN*
}

Makale Gönderme Tarihi: 19 Şubat 2013

Makale Kabul Tarihi: 23 Eylül 2013

\begin{abstract}
ÖZET: $\mathrm{Bu}$ araştırmada okul öncesi öğretmenlerinin dünya vatandaşlığı kavramı ve okul öncesi dönemde dünya vatandaşlı̆ğ eğitimi ile ilgili görüşlerini incelemek amaçlanmıştır. Araştırmada Gallavan (2008) tarafından geliştirilen “21. Yüzyılda Dünya Vatandaşlığı Öğretimi Anket Formu (Teaching World Citizenship in the Twenty-First Century Survey)" kullanılmıştır. Araştırmanın örneklemini, Yalova, Afyonkarahisar, Eskişehir, Aksaray ve Rize illerinde gerçekleştirilen Milli Eğitim Bakanlığı hizmet içi eğitim programlarına ve seminerlerine Türkiye'nin farklı illerinden katılan toplam 345 okul öncesi öğretmeni oluşturmuştur. Araştırmada elde edilen bulgulara göre öğretmenlerin çoğu okul öncesi eğitim programının dünya vatandaşlığını içermesi gerektiğini, çocuklara dünya vatandaşlığını öğretmek istediğini, ancak aldıkları öğretmen eğitim programının ve alan deneyimlerinin çocuklara dünya vatandaşlığını öğretmeye hazırlamadığını belirtmiştir.
\end{abstract}

Anahtar Sözcükler: Dünya vatandaşlığı eğitimi, okul öncesi eğitim, okul öncesi eğitim öğretmeni

\section{Giriş}

Küreselleşme, ulusal ve uluslararası politikalarda hızlı, anlamlı değişim ile ekonomik ve sosyo-kültürel alanlardaki karmaşanın büyümesiyle ilişkilidir (Vidali \& Adams, 2006). Teknolojinin hızla ilerlemesiyle uluslararasındaki ekonomik, ekolojik, sosyal, politik ve kültürel entegrasyon, küreselleşmenin bir parçası olan değişimleri ortaya çıkarmıştır. Dünyanın herhangi bir yerinde meydana gelen bir olay, diğer yerleri etkilemektedir. Bu durum ise insanların, yaşadıkları yere bakılmaksızın, genel olarak uzun veya kısa süreli- aynı yaşantıları edinmelerini sağlamaktadır (Lim, 2008).

Günümüzün küreselleşen ve etkileşimli dünyasında, birlikte barış içinde yaşamak ahlâki, sosyal ve politik bir zorunluluk hâline gelmiştir. Bu yeni dünya düzeninde, bireyleri dünyadaki olayların yalnızca pasif bir gözlemcisi olarak değil; giderek daha da farklılaşan ve karmaşık hâle gelen toplumda birlikte yaşayabilen ve hızlı değişen bilgiyi yakalayabilen, aktif birer dünya vatandaşı olarak yetiştirmek önem kazanmaktadır. Eğitim, tüm dünyanın paylaştığı bu görevde büyük bir rol oynamaktadır (Lim, 2008; Stavenhagen, 2008). Benzer şekilde, eğitim küresel anlayışı geliştiren ve bireyleri küresel vatandaş kültürüne aktif bir katılımcı olarak hazırlayan önemli bir unsur olarak görülmektedir (Evans, Ingram, Macdonald, \& Weber, 2009). Bununla birlikte, dünyadaki etnik, kültür, ırk, dil ve din çeşitliliğinden dolayı, 21. yüzyılda bireyleri etkili birer vatandaş olmaya hazırlayan vatandaşlık eğitiminde uygulanan yöntemlerde değişiklik yapılması gerektiği düşünülmektedir. Bu yüzyıldaki vatandaşlar kendi kültürel topluluklarında ve kültürel sınırlarının dışında aktif olmak için gereken bilgi, tutum ve becerilere gereksinim duymaktadırlar. Vatandaşlar ayrıca, etik ve adil bir toplum olan ulusal vatandaşlık kültürünün yapılanmasına katılmaya gönüllü olmalıdırlar ve kat1labilmelidirler (Banks, 2001; Banks, 2003).

\footnotetext{
*Yard. Doç. Dr., Karabük Üniversitesi, Sağlık Yüksek Okulu, E-posta: sehnazc@gmail.com
} 
Bu bağlamda, vatandaşlık eğitimi, bireylerin kendi kültürel toplumları ile ilgili düşünen ve aydın kimlikler geliştirmelerine yardımcı olmalıdır. Ayrıca, bireylerin dünya toplumundaki rollerine ilişkin derin bir anlayış ve çağdaş küresel kimlikler geliştirmelerine de yardımcı olmalıdır (Diaz, Massialas, \& Xanthopoulos, 1999).

Tuomi, Jacott ve Lundgren (2008) dünya vatandaşlı̆̆ı eğitiminin; hakların eğitimi, eşitlik için eğitim, barış ve medya eğitimi, kültürler arası anlayış için eğitim, sürdürülebilir gelişme için eğitim, uluslararası eğitim, kültürler arası eğitim, kozmopolit vatandaşlık eğitimi ve küresel eğitim alanlarını içermesi gerektiğini belirtmiştir.

Bu açıdan, dünya vatandaşlığı geniş bir kavramdır. İlk olarak, küresel sorunlara ilişkin kapsamlı bilgi ile bu sorunlar için karmaşık güçleri içermektedir. Bir dünya vatandaşı, küresel güçler (fiziksel ve sosyal) ve bunların bireylerin yaşamına etkisi ile ilgili bilgi sahibidir; kültür ve kültürel farklılığı anlar; dünya sorunlarını çeşitli perspektiflerden analiz edebilir ve dünya hakkında yeni fikirler üretebilir. Kısacası, bir dünya vatandaşı iyi gelişmiş bir dizi bilişsel beceriye sahiptir. İkinci olarak, dünya vatandaşı küresel benlik açısından iyi gelişmiş bir benlik duygusuna sahiptir. Bu benlik duygusu, bireyin günden güne ortaya çıkan detayları genişleten kişisel kimliğini içermektedir. Küresel benlik kavramı çok önemlidir. Küresel benlik unsuru olmadan, bir dünya vatandaşı olmak için bilişsel gelişim yeterli olmayacaktır. Son olarak, dünya vatandaşlığı çağdaş dünyaya etkili ve etik bir şekilde dahil olmayı içermektedir. Bu üçüncü unsur, bilgi ve anlayışın, beceri ve motivasyon olarak davranışa dönüşmesini ifade etmektedir. Dünya vatandaşlığının bu üç büyük unsuru birbirini tamamlamakta ve vatandaşlık için gerekli olan özellikleri oluşturmaktadır (Burrows, 2004). Ayrıca, dünya vatandaşlığı eğitimi, çocuklara ve genç bireylere karmaşık sorunlar hakkında eleştirel düşünme becerisini geliştirme fırsatı sunmaktadır (Murray, 2006).

Bireylerin dünya vatandaşı olarak yetişmesinde öğretmenlerin rolü oldukça önemlidir. Öğretmenlerin kalıp yargılardan uzaklaşarak kültürel farklılıkları tanımaları ve çocukların da tanımalarını sağlamaları gerekmektedir (Haydon, 2006). Öğretmenler çok kültürlü dünya toplumunda öğrencilerinin düşünceli, ilgili ve tepki veren vatandaşlar olmalarına yardım etmek için kendi kültürel, ulusal ve küresel kimliklerini geliştirmelidirler (Banks, 2001).

Bunun yanı sıra, okulların ve öğretmenlerin dünya vatandaşlı̆̆ı eğitim programlarını kullanmak ile ilgili motivasyon ve kapasitelerinin düşük düzeyde olması, büyük bir engel oluşturmaktadır. Özellikle, öğretmenlerle ilgili zaman ve güven yetersizliği, okul yöneticileri ve öğretmenlerde nitelikli eğitim yetersizliği; güncel kaynakların yetersizliği ve okuma-yazma, matematik ve bilimi vurgulayan sıkıştırılmış programlar ile karşılaşılmaktadır. Bu bağlamda dünya vatandaşlığının eğitimin bir parçası olarak yer alabilmesi için, akademik personelin, öğretmenlerin ve çocukların farklı yollarla (projelerle) bilinçlendirilmesi gerekmektedir (Davies \& Reid, 2005).

Bireylerin bilgi, beceri ve tutumlarının gelişmesinde kritik dönem olan erken çocukluk yıllarında dünya vatandaşlığı için eğitilmeleri oldukça önem taşımaktadır. Pek çok araştırmacı (Collins, 2008; Dillion, Ruane, \& Kavanagh, 2010; Ebbeck, 2006; Johansson, 2009; Lim, 2008; Yamashita, 2006) dünya vatandaşlı̆̆ eğitiminin okul 
öncesi yıllardan itibaren verilmesi gerektiğini belirtmiştir. Bununla birlikte alan yazına bakıldığında, dünya vatandaşlığı eğitimi ile ilgili araştırmaların daha çok öğretmen adaylarını ve daha üst düzeydeki eğitim alanlarını kapsadığı görülmektedir (Cartwright, Kerrigan, Pusch, Brown, \& Yamashita, 2009; Gallavan, 2008; Gibson, Rimmington, \& Landwehr-Brown, 2008; Golestani, 2006; Haigh, 2008; Rapoport, 2010). Türkiye'de ise dünya vatandaşlığı kavramının son yıllarda ele alınmaya başlandığı ve oldukça sınırlı sayıda araştırma olduğu dikkati çekmektedir (Cevher-Kalburan, Ceylan, \& Kandır, 2009; Durualp \& Durualp, 2012; Kan, 2009a; Kan 2009b; Özyurt, 2009; Tuncel \& Uğur, 2009).

$\mathrm{Bu}$ noktadan hareketle bu araştırmada okul öncesi öğretmenlerinin dünya vatandaşlığı eğitimi ile ilgili görüşlerini belirlemek amaçlanmıştır.

\section{Yöntem}

\section{Araştırmanın Çalışma Grubu}

Araştırmanın çalışma grubunu, Türkiye'deki toplam anasınıfı öğretmen sayısı (28848), 0.95 güven düzeyi (0.10), 0.90 kitle genişliği ve hoşgörü miktarı dikkate alınarak, Yalova, Afyonkarahisar, Eskişehir, Aksaray ve Rize illerinde gerçekleştirilen Milli Eğitim Bakanlığı (MEB) hizmet içi eğitim programlarına ve seminerlerine Türkiye'nin farklı illerinden katılan toplam 345 okul öncesi öğretmeni oluşturmuştur. Çalışmaya katılan öğretmenlerin \%86'sı kadın, \%14'ü erkektir. Öğretmenlerin \%17.1'i 25 yaş ve altında, \%27.8'i 26-29 yaş aralığında, \%25.2'si 30-34 yaş aralığında ve \%29.9'u ise 35 yaş ve üstündedir. Ayrıca, öğretmenlerin \%65.8’i Anaokulu ve Okul Öncesi Öğretmenliği ve \%17.4’ü Çocuk Gelişimi ve Eğitimi lisans programları, \%10.4'ü Çocuk Gelişimi önlisans programı, \%6.4'ü ise lisansüstü eğitim mezunudur. Görev yaptıkları okul türü açısından ise, öğretmenlerin \%69.9'unun MEB'e bağlı ilkokulların bünyesindeki anasınıflarında, \%30.1'inin ise MEB'e bağlı anaokullarında görev yaptıkları belirlenmiştir.

\section{Veri Toplama Aracı}

Veri toplamak amacıyla öğretmenlerin cinsiyeti, yaşı, ailesi ile birlikte yaşadığ 1 yer gibi demografik özelliklerini belirlemeye yönelik "Genel Bilgi Formu” ile okul öncesi öğretmenlerinin çocuklara "dünya vatandaşı” olmayı öğretmeyle ilgili düşüncelerini belirlemeye yönelik "21. Yüzyılda Dünya Vatandaşlığı Öğretimi Anketi (Teaching World Citizenship in the Twenty-First Century Survey)"nin orijinal hali kullanılmıştır. Anket formu, Gallavan (2008) tarafından geliştirilmiştir.

Anket formu, iki yabancı dil uzmanı tarafından İngilizceden Türkçeye ve iki yabancı dil uzmanı tarafından da Türkçeden İngilizceye çevrilmiştir. Orijinal İngilizce formu ile çevirilen İngilizce formu arasında anlamsal bir farklılık olup olmadığına bakılmıştır. Daha sonra, bir Türkçe dil bilimi uzmanı tarafından anket formu ifade ve dil bilgisi yönünden incelenmiştir. Formun son şekli tekrar incelenerek uzman görüşüne hazır hâle getirilmiştir. Hazırlanan "21. Yüzyılda Dünya Vatandaşlığı Öğretimi Anket Formu” dört alan uzmanına görüşleri alınmak üzere gönderilmiştir. Uzmanlardan, 
formda yer alan maddeleri, araştırmanın amacına uygunluk, açıklık ve anlaşılırlık açısından eleştirmeleri, gerekli gördükleri durumlarda maddelerin düzeltilmesi ya da çıkartılması ile ilgili görüşlerini belirtmeleri istenmiştir. Uzman görüşü alındıktan sonra uygulanan anket formu, beş açık uçlu ve altı "evet-hayır" olmak üzere toplam 11 sorudan oluşmaktadır (Cevher-Kalburan ve diğerleri, 2009).

\section{Verilerin Analizi}

Araştırmada elde edilen veriler SPSS 15.0 for Windows paket programında betimsel istatistik yoluyla incelenmiş; öğretmenlerin dünya vatandaşlığı ile ilgili görüşleri frekans dağılımları, yüzdelik değerler ve içerik analizi yöntemleri ile analiz edilmiştir.

\section{Bulgular ve Tartışma}

Okul öncesi öğretmenlerinin dünya vatandaşlığına ilişkin görüşleri Tablo 1 ve Tablo 6 arasında sunulmuş ve tartışılmıştır.

Tablo 1

Okul Öncesi Öğretmenlerinin Okul Öncesi Dönem Çocuklarına Dünya Vatandaşlı̆̆ını Öğretme İle İlgili Görüşlerinin Dă̆ılımı $(n=345)$

\begin{tabular}{|c|c|c|c|c|}
\hline \multirow[t]{2}{*}{ Sorular } & \multicolumn{2}{|c|}{ Evet } & \multicolumn{2}{|c|}{ Hayır } \\
\hline & $n$ & $\%$ & $n$ & $\%$ \\
\hline $\begin{array}{l}\text { 1. 21. Yüzyılda, bir okul öncesi öğretmeni olarak, sınıfınızdaki çocuklara } \\
\text { dünya vatandaşlığını öğretmek istiyor musunuz? }\end{array}$ & 337 & 97.7 & 8 & 2.3 \\
\hline $\begin{array}{l}\text { 2. 21. Yüzyılda, bir okul öncesi öğretmeni olarak, sınıfınızdaki çocuklara } \\
\text { dünya vatandaşlığını öğretmek için hazır olduğunuzu düşünüyor musunuz? }\end{array}$ & 153 & 44.3 & 192 & 55.7 \\
\hline $\begin{array}{l}\text { 3. Mezun olduğunuz öğretmen eğitim programınız sizi sınıfınızdaki } \\
\text { çocuklara dünya vatandaşlığını öğretmek için hazırladı } \mathrm{m} \text { ? }\end{array}$ & 49 & 14.2 & 296 & 85.8 \\
\hline $\begin{array}{l}\text { 4. Öğretmen eğitimi alan deneyimleri, sizi çocuklara dünya vatandaşlığını } \\
\text { öğretmek için hazırladı mı? }\end{array}$ & 76 & 22.0 & 269 & 78.0 \\
\hline $\begin{array}{l}\text { 5. Öğretmen eğitim programları, okul öncesi çocuklarını dünya } \\
\text { vatandaşlığına hazır olmayı öğretmeli midir? }\end{array}$ & 327 & 94.8 & 18 & 5.2 \\
\hline $\begin{array}{l}\text { 6. Okul öncesi çocukları için uygulanan eğitim programı dünya } \\
\text { vatandaşlığını içermeli midir? }\end{array}$ & 331 & 95.9 & 14 & 4.1 \\
\hline
\end{tabular}

Tablo 1 incelendiğinde, öğretmenlerin \%97.7'si dünya vatandaşlığını çocuklara öğretmek istediğini, \%94.8'i öğretmen eğitim programlarının okul öncesi çocuklarını dünya vatandaşlığına hazır olmayı öğretmesi gerektiğini ve \%95.9'u ise okul öncesi çocukları için uygulanan eğitim programının dünya vatandaşlığını içermesi gerektiğini belirtmiştir. Ancak, öğretmenlerin \%85.8'i aldıkları öğretmen eğitim programının çocuklara dünya vatandaşı olmayı öğretmek için hazırlamadığını, \%78'i öğretmen eğitimi alan deneyimlerinin çocuklara dünya vatandaşı olmayı öğretmek için hazırlamadığını ve \%55.7'si ise, çocuklara dünya vatandaşlığını öğretmek için hazır olmadıklarını ifade etmişlerdir. Okul öncesi öğretmenlerinin çoğunun ifadelerine göre, mezun olunan eğitim programlarının ve meslek derslerinin öğretmenleri çocuklara dünya vatandaşlığını öğretmek için hazırlamadığı belirlenmiştir. Bununla beraber 
öğretmenlerin mezun oldukları programların ve okul öncesi çocuklarına uygulanan eğitim programının dünya vatandaşlığı konusunu içermesi gerektiğini düşündükleri de ortaya çıkmıştır.

Rapoport (2010) tarafından gerçekleştirilen çalışmada, öğretmenler her ne kadar eğitim programlarını küresel bakış açısıyla uyguladıklarını ifade etseler de dünya vatandaşlığı öğretimi konusunda rehberlik almaya gereksinimleri olduğu tespit edilmiştir.

Gallavan (2008)'in öğretmen adaylarıyla yaptığı çalışmada da öğretmen adaylarının büyük bir çoğunluğu, çocuklara dünya vatandaşı olmayı öğretmek istediklerini, ancak öğretmen eğitim programları ya da alan deneyimleri açısından kendilerini hazır hissetmediklerini belirtmişlerdir. Bu bulgular, araştırma bulgularını destekler niteliktedir.

Milli eğitim sistemi, öğrencileri iyi birer toplum, bölge, millet ve dünya vatandaş1 hâline getirmeyi, iyi meslek adamı ve sağlıklı nesiller yetiştirmeyi amaçlamaktadır (Sağlam, 2011). Buna göre, okul öncesi öğretmenlerinin çocuklara dünya vatandaşlığını öğretme konusunda istekli oldukları, ancak öğretmenlik eğitim programı içeriğinin dünya vatandaşlığının öğretimi konusunda yeterli olmadığı söylenebilir.

Tablo 2

Okul Öncesi Öğretmenlerinin 21. Yüzyılda "Dünya Vatandaşı Olmak” İle İlgili Görüşlerinin Dă̆ılımı ( $n=345)$

\begin{tabular}{lcc}
\hline Görüşler & $n$ & $\%$ \\
\hline Dünyadaki tüm insanların eşit hak ve özgürlüklere sahip olması, demokrasi & 63 & 23.07 \\
Farklı ırklara, kültürlere saygı duyma, değer verme, kabul etme ve hoşgörü & 35 & 12.82 \\
Gelişen teknolojiye, bilime, topluma uyum sağlayan, aynı zamanda kendi öz değerlerini, & 25 & 9.15 \\
kültürünü muhafaza edebilmiş çağdaş birey olma & \\
Çevre duyarlılığı ve bilinci & 24 & 8.79 \\
Dünyayı tanımak, diğer ülkeleri takip etmek & 22 & 8.05 \\
Evrensel değerlerin olması & 21 & 7.70 \\
Sınırların olmadığı bir dünyada tüm insanların sevgi, barış ve birliktelik içinde olması & 20 & 7.32 \\
Bilgim/fikrim yok & 17 \\
Globalleşme & 6.23 \\
Ülkeler arasında özgür dolaşma & 12 \\
Kendine ve çevresindekilere faydalı bir birey olma & 4.40 \\
Çok önem ve gerekli & 4.02 \\
Dünyadaki olaylara, sorunlara karşı sosyal duyarlılık & 8 & 2.94 \\
Bir ütopyadır & 7 & 2.57 \\
Dünyanın geleceğini ve varlı̆̆ını sürdürmeyi hedeflemek & 4 & 1.47 \\
Toplam & 3 & 1.10 \\
\hline
\end{tabular}

Tablo 2'ye bakıldığında, öğretmenlerin \%23.07'si dünya vatandaşı olmayı "Dünyadaki tüm insanların eşit hak ve özgürlüklere sahip olması, demokrasi", \%12.82'si “Farklı 1rklara, kültürlere saygı duyma, değer verme, kabul etme ve hoşgörü”, \%9.15'i “Gelişen teknolojiye, bilime, topluma uyum sağlayan, aynı zamanda kendi öz değerlerini, kültürünü muhafaza edebilmiş çağdaş birey olma”, \%8.79’u “Çevre duyarlılığı ve bilinci”, \%8.05'i "Dünyayı tanımak, diğer ülkeleri takip etmek", 
\%7.70’i "Evrensel değerlerin olması", \%7.32 "Sınırların olmadığı bir dünyada tüm insanların sevgi, barış ve birliktelik içinde olması”, \%4.40’1 “Globalleşme”, \%4.02'si "Ülkeler arasında özgür dolaşma”, \%2.94'ü "Kendine ve çevresindekilere faydalı bir birey olma”, \%2.57’si “Çok önem ve gerekli”, \%1.47’si “Dünyadaki olaylara, sorunlara karşı sosyal duyarlılık”, \% 1.10’u “Bir ütopyadır”, \%0.37'si "Dünyanın geleceğini ve varlığını sürdürmeyi hedeflemek” şeklinde tanımlamıştır. Öğretmenlerin \%6.23’ü ise dünya vatandaşı olma ile ilgili herhangi bir fikrinin olmadığını ifade etmişlerdir.

Tuomi, Jacott ve Lundgren (2008), yaptıkları çalışmada dünya vatandaşlığ eğitiminde "insan hakları", "sosyal adalet ve eşitlik", "kültürel çeşitlilik" gibi temel kavramları vurgulamışlardır. Kemp (2005), adalet ve hak kavramlarının dünya vatandaşlığı için çok önemli değerler olduğu düşüncesindedir (Aktaran: Johansson, 2009). Bu bulgular, dünya vatandaşı olma ile ilgili öğretmenlerin çoğunluğunun vurguladığı "dünyadaki tüm insanların eşit hak ve özgürlüklere sahip olması, demokrasi” ve "Farklı 1rklara, kültürlere saygı duyma, değer verme, kabul etme ve hoşgörü” kavramlarıyla örtüşmektedir.

Dünya vatandaşlığı, tüm insanları kapsayacak ölçüde geniş bir anlama sahiptir. Dünya vatandaşlığı, ayrıca, tüm vatandaşlarda dünyaya, insanlığa ve farklı kültürlere yönelik bir farkındalığı ifade eder (Özyurt, 2009). Dünya vatandaşlığının tanımında da vurgulandığı gibi okul öncesi öğretmenlerinin de dünya vatandaşlığı kavramıyla ilgili "evrensel değerler”, "sınırların olmadığı bir dünyada tüm insanların sevgi, barış ve birliktelik içinde olma”, “dünyadaki olaylara, sorunlara karşı sosyal duyarlılık" konularına özellikle vurgu yaptıkları görülmüştür. 
Tablo 3

Öğretmenlerin Okul Öncesi Dönem Çocuklarını Dünya Vatandaşı Olarak Hazırlamak İçin Program İçeriğinin Nelerden Oluşması Gerektiği İle İlgili Görüşlerinin Dă̆ılımı $(n=345)$

\begin{tabular}{lcc}
\hline Görüşler & $n$ & $\%$ \\
\hline Farklı kültürleri, ülkeleri tanıtıcı etkinlikler & 50 & 20.41 \\
Çevre duyarlılığı ve bilinci & 34 & 13.88 \\
İnsan hak ve özgürlüklerine dayalı etkinlikler & 27 & 11.02 \\
Bilgim/fikrim yok & 23 & 9.39 \\
Farklılıklara saygı ve evrensel değerler & 22 & 8.98 \\
Farklı kültürleri bir araya getiren çalışmalar (kaynaştırma) & 15 & 6.12 \\
Sevgi eğitimi (insan, hayvan vb.) & 12 & 4.90 \\
Yabancı dil eğitimi & 11 & 4.50 \\
Güncel ve sosyal konulara duyarlılık & 7 & 2.86 \\
Çocukların kendilerini ifade edebilecekleri, gerçekleştirebilecekleri ve geliştirebilecekleri & 7 & 2.86 \\
uygulamaya dayalı bir program & & \\
Demokratik düşünmeye dayalı etkinlikler & 6 & 2.45 \\
Öncelikle kendi kültürünü, daha sonra diğer kültürleri tanıması & 5 & 2.04 \\
Bu konuda evrensel bir eğitim programının hazırlanması ve uygulaması & 5 & 2.04 \\
Öğretmenlere dünya vatandaşlığı kavramının tanıtılması, ögretilmesi & 5 & 2.04 \\
Değerler eğitimi & 5 & 2.04 \\
Sorumluluk eğitimi & 5 & 2.04 \\
Ülke koşulları dikkate alınarak hazırlanan program & 3 & 1.23 \\
Dünya çocuklarının ortak sorunlarının tespiti ve çözümlerin belirlenmesi & 1 & 0.40 \\
Kitle iletişim araçlarının kullanımı & 1 & 0.40 \\
Dünya haritası & 1 & 0.40 \\
Toplam & 245 & 100 \\
\hline
\end{tabular}

Tablo 3'e göre öğretmenlerin çoğunun (\%20.41), okul öncesi dönem çocuklarını dünya vatandaşı olarak hazırlamak için program içeriğinin farklı kültürleri ve ülkeleri tanıtıcı etkinliklerden oluşması gerektiğini ifade ettikleri saptanmıştır. Bunu takiben programda çevre duyarlılığı ve bilincinin (\%13.88) ve insan hak ve özgürlüklerine dayalı etkinliklerin (\%11.02) yer alması gerektiği de vurgulanmaktadır. Bununla beraber, okul öncesi çocukları için program içeriği hakkında fikri olmadığını belirtenlerin oranının (\%9.39) diğer ifadelere göre yüksek olduğu dikkat çekmektedir.

Dillon, Ruane ve Kavanagh (2010), yaptıkları çalışmada çocukların, yaş ve gelişim düzeylerine uygun olarak, dünya ve adalet hakkında sahip oldukları bilgi ve becerilerinin firsatlar sağlanarak desteklenmesi ve özellikle geniş bir dünya görüşü için kültürlerle ilgili görüşlerin vurgulanması gerektiğini belirtmişlerdir.

Yaşar (2009), sosyal bilgiler öğretmenliği lisans programında dördüncü sınıfa devam eden 35 öğretmen adayının dünya vatandaşlığına ilişkin algılarını belirlemek için yaptığı araştırmada, öğretmen adaylarının dünya vatandaşlığ 1 kapsamında sorumluluk ve saygı kavramlarını ön plana çıkardıklarını belirtmiştir.

Collins (2008), temel ihtiyaçlar, çevre sorunları, çeşitli kültürler, insan hakları, demokrasi, dünya sorunları gibi konuların, 4-6 yaş çocuklarının dünya vatandaşlığını öğrenebilmelerinde önemli olduğunu vurgulamıştır. 
Tuomi, Jacott ve Lundgren (2008) yaptıkları araştırmada, dünya vatandaşlığ eğitiminde; farklı ülkelerdeki insanların duyguları, gereksinimleri ve yaşamları için empati, çevre ile ilgilenme, sosyal hak ve eşitliğe bağl1lık, kültürel çeşitliliğe değer verme ve saygı duyma ile sorumluluk duygusu gibi kazandırılması gereken değer ve tutumları vurgulamışlardır.

$\mathrm{Bu}$ bulgular, araştırmada elde edilen dünya vatandaşlığı program içeriğinde öğretmenlerin olması gerektiğini vurguladığı; "farklı kültürleri, ülkeleri tanıtıc1 etkinlikler", "çevre duyarlılığı ve bilinci”, "insan hak ve özgürlüklerine dayalı etkinlikler", "farklılıklara saygı ve evrensel değerler", "demokratik düşünmeye dayalı etkinlikler”, "sorumluluk eğitimi” ve "değerler eğitimi” konularılla ilgili görüşlerini destekler niteliktedir.

Tablo 4

Öğretmenlerin Okul Öncesi Dönem Çocuklarını Dünya Vatandaşı Olmaya Hazırlamak İçin Hangi Öğretim Stratejilerini Kullanmak Gerektiği İle İlgili Görüşlerinin Dağılımı $(n=345)$

\begin{tabular}{lcc}
\hline Görüşler & $n$ & $\%$ \\
\hline Aktif öğrenme (yaparak-yaşayarak) & 45 & 16.07 \\
Gezi-gözlem & 44 & 15.71 \\
Bilgim/fikrim yok & 33 & 11.79 \\
Görsel eğitim & 30 & 10.71 \\
Drama & 25 & 8.93 \\
İnceleme-araştırma & 17 & 6.07 \\
Eğitim teknolojileri (bilgisayar, internet, tepegöz, slayt vb) & 13 & 4.64 \\
Tüm etkinlikler ve stratejiler & 13 & 4.64 \\
Düz anlatım & 11 & 3.94 \\
Buluş yoluyla öğrenme & 5 & 1.79 \\
Oyun & 5 & 1.79 \\
Öykü & 5 & 1.79 \\
Farklı kültürden insanları davet etme & 4 & 1.43 \\
Örnek olay & 4 & 1.43 \\
Aile eğitimi/katılımı & 4 & 1.43 \\
Problem çözme & 4 & 1.43 \\
Çoklu zekâ & 3 & 1.07 \\
Sunuş yoluyla öğrenme & 3 & 1.07 \\
Proje temelli öğretim & 3 \\
Soru -yanıt & 1.07 \\
Beyin firtınası & 2 & 0.71 \\
Tartışma & 2 & 0.71 \\
Çizgi film & 2 & 0.71 \\
Belgesel & 2 & 0.71 \\
Toplam & 1 & 0.36 \\
& & 100 \\
\hline
\end{tabular}

Tablo 4’te, öğretmenlerin çoğu (\%16.07) okul öncesi dönem çocuklarını dünya vatandaşı olmaya hazırlamak için yaparak-yaşayarak öğrenme firsatları sunulması gerektiğini ifade etmişlerdir. Bununla birlikte, öğretmenlerin gezi-gözlem, görsel eğitim, drama yöntemi, inceleme-araştırma, eğitim teknolojileri, tüm etkinlikler ve stratejiler, düz anlatım, buluş yoluyla öğrenme, oyun, öykü, farklı kültürden insanları davet etme, örnek olay, aile eğitimi/katılımı, problem çözme, çoklu zekâ, sunuş yoluyla 
öğrenme, proje temelli öğretim, soru-cevap yöntemi, beyin firtınası, tartışma, çizgi film ve belgesel gibi öğretim yöntem ve tekniklerini de kullanmak gerektiğini belirttikleri görülmektedir. Öğretmenlerin \%11.79’u ise, herhangi bir fikrinin olmadığını ifade etmişlerdir.

Evans, Ingram, Macdonald ve Weber (2009), dünya vatandaşlığını öğretme ve öğrenme uygulamalarıyla ilgili etkileşimli öğretim ve öğrenme yaklaşımları, uygulamalı eğitimler ile deneyimsel öğrenme stratejilerinin önemini vurgulamışlardır. Lim (2008), çocukların dünya vatandaşlığını öğrenebilmeleri için deneyim ve görsel eğitimin çok önemli olduğunu vurgulamıştır. Bunun için oyun, bilgisayar, kitle iletişim araçları, rol oynama ve öykülerin etkili kullanılabileceğini belirtmiştir. Bu bulgular, çocukları dünya vatandaşlığına hazırlamak için öğretmenlerin çoğunun aktif öğrenme (yaparakyaşayarak) yönteminin kullanılmasıyla ilgili görüşlerini destekler niteliktedir. Drama yöntemi, oyun, gezi-gözlem, soru-cevap yöntemi, beyin firtınası, problem çözme, proje temelli öğretim, buluş ve sunuş yoluyla öğretim gibi öğretim yöntemlerinin temelinde yaparak-yaşayarak öğrenme fırsatı yattığından öğretmen adaylarının çocukları etkin kılan farklı ögrenme stratejilerini tercih ettikleri söylenebilir.

\section{Tablo 5}

Öğretmenlerin Okul Öncesi Dönem Çocuklarına Dünya Vatandaşı Olmayı Öğretme Konusunda Kendilerine Hangi Gelişim Fırsatlarının Sunulması Gerektiği İle İlgili Görüşlerinin Dă̆llımı ( $n=345)$

\begin{tabular}{lcc}
\hline Görüşler & $n$ & $\%$ \\
\hline Seminer, toplantı, kongre, kurs, konferans, workshop & 88 & 33.21 \\
Okul öncesi eğitimiyle ilgili farklı kültürlere gezi-gözlem & 47 & 17.74 \\
Hizmet içi eğitim & 40 & 15.09 \\
Kaynak kitap, dergi, materyal ve dokümanlar & 16 & 6.04 \\
Bilgim/fikrim yok & 16 & 6.04 \\
Yurt dışı değişim programları ve projeler & 15 & 5.66 \\
Eğitim programları & 12 & 4.53 \\
Uygulamalı eğitimler & 9 & 3.40 \\
Öğretmen eğitimi programına dünya vatandaşlığı dersinin eklenmesi & 8 & 3.02 \\
Yabancı dil eğitimi & 5 & 1.89 \\
Bilgisayar eğitimi & 5 & 1.89 \\
Rehberlik & 2 & 0.75 \\
Bilim-Kültür & 1 & 0.37 \\
Firsat eğitimi & 1 & 0.37 \\
Toplam & 265 & 100 \\
\hline
\end{tabular}

Tablo 5 incelendiğinde, bu konuda kendilerini geliştirmeleri için öğretmenlerin \%33.21'i seminer, toplantı, kongre, kurs, konferans, workshop düzenlenmesi gerektiğini \%17.74'ü okul öncesi eğitimiyle ilgili farklı kültürlere gezi-gözlem yapılması gerektiğini, \%12.87'si yurt dışında eğitim olanağının sağlanması gerektiğini, \%15.09’u hizmet içi eğitim yapılması gerektiğini, \%6.04’ü kaynak kitap, dergi, materyal ve dokümanlar gerektiğini, \%5.66'sı yurt dışı değişim programlarının ve projelerin planlanması gerektiğini, \%4.53’ü eğitim programlarının hazırlanması gerektiğini, 
\%3.40'1 uygulamalı eğitimlerin hazırlanması gerektiğini, \%3.02'si öğretmen eğitimi programına dünya vatandaşlığı dersinin eklenmesi gerektiğini, \%1.89’u yabancı dil ve bilgisayar eğitiminin gerekliliğini, \%0.75'i rehberliğin gerekliliğini ve \%0.37'si bilimkültür ve fırsat eğitimlerinin sağlanması gerektiğini belirtmektedir. Buna karşılık öğretmen adaylarının \% 6.04'ü herhangi bir fikrinin olmadığını ifade etmektedir.

Gibson, Kimmington ve Landwehr-Brown (2008), öğretmenlerin dünya vatandaşlığıyla ilgili bilgi, beceri ve tutumlarını geliştirmeleri için, dünyanın başka bir yerindeki bir öğretmen ile işbirliği yapmanın, deneyime dayalı eğitimlerin, modern iletişim teknolojilerinin kullanılmasının gerekliliğini vurgulamaktadır. Gibson ve diğerlerinin (2008) araştırma sonuçları, öğretmenlerin dünya vatandaşlı̆̆ı ile ilgili kendilerini geliştirmeleri için farklı kültürlere gezi-gözlem, yurt dışı değişim programları ve projeler, bilgisayar eğitimi gibi fırsatların sunulması gerektiğiyle ilgili görüşlerini destekler niteliktedir. Ayrıca, öğretmenler bu konuyla ilgili seminer, toplantı, kongre, kurs, konferans, workshop, hizmet içi eğitim, uygulamalı eğitim, fırsat eğitimi, kaynak kitap, dergi, materyal ve dokümanlara ihtiyaç duyduklarını belirtmişlerdir. Buna göre öğretmenlerin bu konuda kapsamlı bir eğitime gereksinim duydukları söylenebilir.

\section{Tablo 6}

Öğretmenlerin Okul Öncesi Dönem Çocuklarına Dünya Vatandaşı Olmayı Öğretme Konusundaki Endişeleri İle İlgili Görüşlerinin Dağılımı (n=345)

\begin{tabular}{lcc}
\hline Görüşler & $\mathrm{n}$ & $\%$ \\
\hline Yeterli bilgiye sahip olmadığı için çocuklara kazandıramamak & 35 & 18.72 \\
Endişe duymuyorum & 17 & 9.09 \\
Bilgim/fikrim yok & 17 & 9.09 \\
Kültürel yozlaşma/asimile olma/kendi-milli değerlerinden uzaklaşma & 17 & 9.09 \\
Toplum olarak hazır olmama & 16 & 8.56 \\
Toplumdaki kalıp yargılar (dini baskı, cehalet, önyargılar, engelleme gibi) & 12 & 6.42 \\
Okul ve aileler tarafindan desteklenmeme & 12 & 6.42 \\
Her öğretmenin yeterince duyarlı olmaması & 11 & 5.88 \\
Çocukların tam olarak anlayamaması (soyut bir kavram) & 9 & 4.81 \\
Kaynakların-imkânların yetersizliği (materyal, kitap vb.) & 9 & 4.81 \\
Uygulanan eğitim politikaları & 3.21 \\
Tüm ülkeye-dünyaya yaygınlaştıramama & 6 & 3.21 \\
Dünyanın-toplumların kötüye gitmesi (şiddet, savaş vb.) & 6 & 3.21 \\
Programın amacına uygun işlenmemesi & 6 & 3.15 \\
Dil problemi (farklı dillerin konuşulması) & 4 & 2.15 \\
Televizyon programlarının olumsuz etkileri & 3 & 1.60 \\
Eğitime geç kalınması & 3 & 1.60 \\
Çocukların ve velilerin sosyo-kültürel farklılıkları & 2 & 1.07 \\
Çocukların dikkatini çekecek şekilde sunulmaması & 1 & 0.53 \\
Toplam & 1 & 0.53 \\
\hline
\end{tabular}

Tablo 6'da, öğretmenlerin okul öncesi dönem çocuklarına dünya vatandaş1 olmayı öğretme konusundaki endişeleri incelendiğinde, ilk sırada öğretmenin yeterli bilgiye sahip olmadığı için çocuklara dünya vatandaşı olmayı kazandıramaması (\%18.72), ikinci sırada kültürel yozlaşma/asimile olma/kendi-milli değerlerinden 
uzaklaşma (\%9.09), üçüncü sırada toplum olarak hazır olmama (\% 8.56) yer almaktadır. Öğretmenlerin diğer endişeleri ise, toplumdaki kalıp yargılar, okul ve aileler tarafından desteklenmeme, her öğretmenin yeterince duyarlı olmaması, çocukların tam olarak anlayamaması, kaynakların-imkânların yetersizliği, uygulanan eğitim politikaları, tüm ülkeye-dünyaya yaygınlaştıramama, dünyanın-toplumların kötüye gitmesi, programın amacına uygun işlenmemesi, dil problemi, televizyon programlarının olumsuz etkileri, eğitime geç kalınması, çocukların ve velilerin sosyo-kültürel farklılıkları, çocukların dikkatini çekecek şekilde sunulmaması şeklinde sıralanabilir. Öğretmenlerin \%9.09’u endişe duymadıklarını, yine \%9.09'u bu konuyla ilgili fikrinin olmadığını belirtmiştir.

Rapoport (2010) yaptığı çalışmada öğretmenlerin dünya vatandaşlığına karşı olumlu tutuma sahip olduklarını ancak bu tutumlarını sınıf uygulamalarına yansıtma konusunda öz-yeterlik düzeylerinin yükseltilmesi gerektiğini belirtmiştir. Ayrıca, öğretmenlerin dünya vatandaşlığı öğretiminde yöntem, içerik ve program konularında yardıma gereksinimleri olduğunu tespit etmiştir. Bu bulgular, öğretmenlerin çocuklara dünya vatandaşı olmayı öğretme konusundaki endişeleriyle ilgili çoğunluğun belirttiği "yeterli bilgiye sahip olmadığım için çocuklara kazandıramamak" görüşünü destekler niteliktedir. Okul öncesi dönemdeki çocuklara bu konuyu öğretmek için öğretmenlerin yardıma gereksinim duydukları söylenebilir.

\section{Sonuç ve Öneriler}

Dünya vatandaşı olmanın sorumluluğunu kavrayan insanların artırılması, hem bireysel hem kurumsal hem de ülkeler arasında başarılı olmanın en önemli etmenlerinden biridir. Dünya vatandaşlı̆̆ı kavramı; çocukların hem kendileri hem başkaları hem de dünya ile ilgili duyarlılık kazanmalarını sağlamaktadır. Özellikle küçük yaşlardan itibaren insan olmanın, dünya vatandaşı olmanın hak ve sorumluluklarının öğretilmesi gerekmektedir. Okul öncesi eğitim çocukların başkalarıyla etkileşime girmesini sağlayarak dünya ile ilgili bakış açılarını geliştirme firsatı sunmaktadır. Bu nedenle dünya vatandaşlığı kavramının kazandırılmasında okul öncesi eğitim öğretmenlerine büyük sorumluluklar düşmektedir.

Araştırmada elde edilen bulgulara göre öğretmenlerin çoğu okul öncesi eğitim programının dünya vatandaşlığını içermesi gerektiğini, çocuklara dünya vatandaşlığını öğretmek istediğini, ancak aldıkları öğretmen eğitim programının ve alan deneyimlerinin çocuklara dünya vatandaşlığını öğretmeye hazırlamadığını belirtmiştir.

Ayrıca, öğretmenlerin çoğunun dünya vatandaşı olmayı, dünyadaki tüm insanların eşit hak ve özgürlüklere sahip olması ve demokrasi kavramlarıyla açıkladığı görülmektedir. Öğretmenlerin büyük çoğunluğu, okul öncesi dönem çocuklarını dünya vatandaşı olarak hazırlamak için program içeriğinin farklı kültürleri ve ülkeleri tanıtıcı etkinliklerden oluşması gerektiğini ifade etmiştir. Öğretmenlerin çoğu, okul öncesi dönem çocuklarını dünya vatandaşı olmaya hazırlamak için onlara yaparak-yaşayarak öğrenme firsatları sunulması ve bu konuda onların kendilerini geliştirmeleri için seminer, toplant1, kongre, kurs, konferans, workshop düzenlenmesi gerektiğini ifade etmişlerdir. Öğretmenlerin okul öncesi dönem çocuklarına dünya vatandaşı olmayı 
öğretme konusundaki endişelerinde ilk sırayı yeterli bilgiye sahip olmadıkları için çocuklara dünya vatandaşı olmayı kazandıramamanın aldığı belirlenmiştir.

\section{Öneriler}

Bu sonuçlar doğrultusunda;

- Okul öncesi öğretmeni yetiştiren öğretim programlarında dünya vatandaşlı̆̆ ve okul öncesi dönem çocuklarına öğretilmesi ile ilgili seçmeli derslere yer verilmesi,

- Okul öncesi eğitim programına dünya vatandaşlığının kazanımına yönelik amaç ve kazanımların konulması,

- Üniversiteler, devlet kurumları ve özel kuruluşların işbirliği ile dünya vatandaşlığı konusunda uluslararası katılımlı kongre, konferans, seminer, panel ve workshop gibi bilimsel etkinlikler düzenlenmesi,

- Dünya vatandaşlığıyla ilgili daha fazla eğitimciye ulaşmak amacıyla hizmet içi eğitimlerde bu konuya yer verilmesi,

- Okul öncesi öğretmenlerinin farklı disiplinlerdeki eğitimcilerle bu konuyu paylaşmalarının ve bilgi alış verişinde bulunmalarının sağlanması,

- Okul öncesi eğitim öğretmenlerinin dünya vatandaşlı̆̆ kavramıyla ilgili bakış açılarını genişletebilmeleri, diğer öğretmenlerle işbirliği yapmaları ve deneyim elde etmeleri için farklı kültürlere gezi-gözlem yapma, yurt dışı değişim programları ve projelere katılma gibi firsatların sağlanması,

- Dünya vatandaşlığını öğretme ve öğrenme uygulamalarının daha etkili olabilmesi için aktif ve deneyimsel öğrenme stratejilerinin kullanılması,

- Buna yönelik etkinlikler, uygun yöntem, strateji ve materyaller içeren eğitim kitleri ve paket programlar hazırlanarak öğretmenlerin bunlara ulaşmasının sağlanmas1,

- $\mathrm{Bu}$ konuda öğretmenlerin uygulamalarının desteklenmesi amacıyla okul yöneticileri ve ailelerin katılımlarının sağlanması,

- Çocuklara, öğretmenlere ve öğretmen adaylarına dünya vatandaşlığı ile ilgili eğitim programları uygulanarak bunların etkisinin incelenmesi,

- Tüm kamu ve özel kuruluşların işbirliği ile iletişim teknolojilerinden yararlanılarak topluma bu konuda farkındalık ve duyarlılık kazandırmaya yönelik çalışmaların artırılması önerilebilir.

\section{Kaynakça}

Banks, J. A. (2001). Citizenship education and diversity: Implications for teacher education. Journal of Teacher Education, 52(1), 5-16.

Banks, J. A. (2003). Introduction: Democratic citizenship education in multicultural societies. In J. A. Banks (Ed.), Diversity and citizenship education: Global perspectives (pp.3-15) San Francisco: Jossey-Bass. 
Burrows, D. (2004, October). World citizenship. Paper presented at the American Council on Education Regional Conference on New Directions in International Education, Beloit, Wisconsin.

Cartwright, C., Kerrigan, P., Pusch, M. P., Brown, K., \& Yamashita, M. (2009). Global citizenship; challenges and opportunities for U.S. higher education. Retrieved from http://www.aacu.org/meetings/annualmeeting/AM09/documents/GlobalCitizenship PowerPoint.pdf

Collins, M. (2008). Global citizenship for young children (Lucky Duck Books).United States:Sage Publications.

Davies, I., \& Reid, A. (2005). Globalising citizenship education? A critique of 'global education' and 'citizenship education'. British Journal of Educational Studies, 53(1), 66-89.

Diaz, C. F., Massialas, B. G., \& Xanthopoulos, J. A. (1999). Global perspectives for educators. Boston: Allyn \& Bacon.

Dillon, S., Ruane, B., \& Kavanagh, A. M. (2010). Young children as global citizens. Policy \& Practice: A Development Education Review, 11, 84-91. Retrieved from http://www.developmenteducationreview.com/issue11-perspectives3

Durualp, E., \& Durualp, E. (2012). İlköğretim II. kademede öğrenim gören öğrencilerin evrensel değerlere ilişkin tutumlarının incelenmesi. Kuramsal Eğitimbilim Dergisi, 5(4), 484-499. http://www.keg.aku.edu.tr adresinden alınmıştır.

Evans, M., Ingram, L. A., Macdonald, A., \& Weber, N. (2009). Mapping the "global dimension" of citizenship education in Canada: The complex interplay of theory, practice and context. Citizenship Teaching and Learning, 5(2), 17-34.

Ebbeck, M. (2006). The challenges of global citizenship: Some issues for policy and practice in early childhood. Childhood Education: Association for Childhood Education International, 82(6), 353-358.

Gallavan, N. P. (2008). Examining teacher candidates' views on teaching world citizenship. The Social Studies, 99(6), 249-254.

Golestani, C. (2006). Teaching for social justice and global citizenship (Unpublished doctoral dissertation). California University, Los Angeles, CA.

Gibson, K. L., Rimmington, G. M., \& Landwehr-Brown, M. (2008). Developing global awareness and responsible world citizenship with global learning. Roeper Review, 30(1), 1-23.

Haigh, M. (2008). Internationalisation, planetary citizenship and Higher Education Inc. Compare: A Journal of Comparative and International Education, 38(4), 427-440.

Haydon, G. (2006). Respecting for persons and for cultures as a basis for national and global citizenship. Journal of Moral Education, 35(4), 457-471.

Johansson, E. (2009). The preschool child of today-the world citizen tomorrow? International Journal of Early Childhood, 41(2), 79-95. 
Kan, Ç. (2009a). Değişsen değerler ve küresel vatandaşlık eğitimi. Kastamonu Eğitim Dergisi, 17(3), 895-904.

Kan, Ç. (2009b). Sosyal bilgiler eğitiminde küresel vatandaşlık. Pamukkale Üniversitesi Eğitim Fakültesi Dergisi, 26, 25-30.

Lim, C. P. (2008). Global citizenship education, school curriculum and games: Learning mathematics, English and science as a global citizen. Computers \& Education, 51, 1073-1093.

Murray, S. (2006). Editorial. Policy \& Practice: A Development Education Review, 3, $1-4$.

Özyurt, C. (2009). Küresel vatandaşlığın gelişimi imkânı ve küresel değerler eğitimi. 1. Uluslararası Avrupa Birliği, Demokrasi, Vatandaşlık ve Vatandaşlık Eğitimi Sempozyumu Bildiri Kitabl, 159-166. http://www.kaynakca.info/eser_dosya/1_eupecitpapers.pdf adresinden alınmıştır.

Rapoport, A. (2010). We cannot teach what we don't know: Indiana teachers talk about global citizenship education. Education, Citizenship and Social Justice, 5(3), 179190.

Sağlam, H. İ. (2011). Öğretmen adaylarının etkili vatandaşlık yeterlik düzeyleri. Kastamonu Eğitim Dergisi, 19(1), 39-50.

Stavenhagen, R. (2008). Building interculturel citizenship through education: A human rights approach. European Journal of Education, 43(2), 161-179.

Tuncel, G., \& Uğur, C. A. (2009). İlköğretim 8. sınıf öğrencilerinin "küresel vatandaşl1k" kavramına yükledikleri anlamlar üzerine bir değerlendirme. I. Uluslararası Avrupa Birliği, Demokrasi, Vatandaşlık ve Vatandaşlık Ĕ̆itimi Sempozyumu Bildiri Kitabl, 229-232. http://www.kaynakca.info/eser_dosya/1_eupecitpapers.pdf adresinden alınmıştır.

Tuomi, M. T., Jacott, L., \& Lundgren, U. (2008). Education for world citizenship: Preparing students to be agents of social change. London: The CiCe Thematic Network Project.

Vidali, E. L., \& Adams, L. D. (2006). The challenges of globalization: changes in education policy and practice in the Greek context. Association for Childhood Education International, 82(6), 358-362.

Yamashita, H. (2006). Global citizenship education and war: The needs of teachers and learners. Educational Review, 58(1), 27-39.

Yaşar, Ş. (2009, Mart). Küreselleşme ve dünya vatandaşlığı. E-gazete. http://egazete.anadolu.edu.tr/ayrinti.php?no=7628 adresinden alınmıştır. 